\begin{tabular}{|l|c|c|c|c|}
\hline $\begin{array}{l}\text { Cuadernos de Investigación Geográfica } \\
\text { Geographical Research Letters }\end{array}$ & 2019 & $\mathbf{N}^{\circ} 45(1)$ & pp. 393-416 & eISSN 1697-9540 \\
\hline
\end{tabular}

\title{
CLIMATE REGIONALIZATION AND TRENDS BASED ON DAILY TEMPERATURE AND PRECIPITATION EXTREMES IN THE SOUTH OF THE PAMPAS (ARGENTINA)
}

\author{
F. FERRELLI ${ }^{1,2 *}$, A.S. BRENDEL ${ }^{1,2,3}$, V.S. ALIAGA ${ }^{1}$, \\ M.C. PICCOLO ${ }^{1,2}$, G.M.E. PERILLO ${ }^{1,4}$
}

\begin{abstract}
${ }^{1}$ Instituto Argentino de Oceanografía (IADO), Universidad Nacional del Sur (UNS)-CONICET, Florida 8000 (Camino Carrindanga km 7,5), Complejo CCT CONICET, Edificio E1, Bahía Blanca, Argentina. ${ }^{2}$ Universidad Nacional del Sur, Departamento de Geografía y Turismo, 12 de Octubre $1198,4^{\circ}$ piso, Bahía Blanca, 8000, Argentina. ${ }^{3}$ Universidad Nacional del Sur, Departamento de Agronomía, San Andrés 800, Bahía Blanca, Argentina. ${ }^{4}$ Universidad Nacional del Sur, Departamento de Geología, Avenida Alem 1253, $2^{\circ}$ piso, Bahía Blanca, 8000, Argentina.
\end{abstract}

\begin{abstract}
The south of Pampas ( $36^{\circ} 32^{\prime}-40^{\circ} 44^{\prime} \mathrm{S}$; $\left.63^{\circ} 24^{\prime}-60^{\circ} 30^{\prime} \mathrm{W}\right)$, as most of Argentina, is a semiarid region. Its economy is based on rain-fed agriculture and livestock. Traditionally, the climate has been studied considering the analyses of monthly and annual climate parameters, but there is evidence that in this type of areas, the short-term climatic events have a substantial impact on the climate. Therefore, this study aimed at developing a climate regionalization from the analysis of daily temperature and precipitation extremes in the south of the Pampas for the period 1970-2017. Subsequently, it focuses on analyzing both trends and breakpoints of these events in the different sub-climates. To do so, we applied a Cluster-based Principal Component Analyses with a Ward hierarchical supervised method to generate a climate regionalization considering 29 daily extreme climatic indices and the elevation. We identify four sub-regions, and we analyzed trends during 1970-2017, and in the two-time series defined by applying breakpoints. Both minimum and maximum temperatures and precipitation had structural changes in the last 15 years, exposing the region to warming and dryness trends. The maximum temperature increases $0.5^{\circ} \mathrm{C}$, while precipitation decreases $30 \mathrm{~mm}$. The short-term climate variability allows us to identify areas climatically more detailed and to conclude that the south of the Pampas is characterized by its high dependency on short-term climatic events.
\end{abstract}

Regionalización y tendencias climáticas basadas en eventos extremos térmicos y pluviométricos diarios en el sur de la Región Pampeana (Argentina)

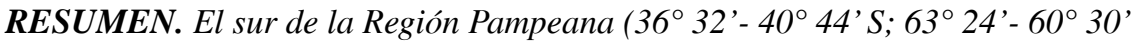
$W)$ es, al igual que la mayor parte de Argentina, una región semiárida. Su economía se basa en la agricultura de secano y la ganadería. Tradicionalmente, el clima 
ha sido estudiado considerando los eventos térmicos y pluviométricos mensuales y anuales. Sin embargo, existe evidencia científica de que los eventos climáticos a corto plazo (diarios) tienen un impacto sustancial en el clima. El objetivo de este trabajo es desarrollar una regionalización climática a partir del análisis de las temperaturas y precipitaciones diarias extremas en el sur de la Región Pampeana durante el período 1970-2017. Complementariamente, este trabajo se enfoca en analizar las tendencias de estos eventos en cada sub-clima durante dos períodos de tiempo de la serie 1970-2017. Para generar la regionalización, aplicamos un Análisis de Componentes Principales y un Análisis de Conglomerados utilizando el método supervisado de Ward, considerando 29 índices climáticos extremos diarios y la elevación. Como resultado obtuvimos cuatro subregiones. Además, analizamos la tendencia de los 29 índices climáticos extremos diarios durante el período 1970-2017 y en dos sub-series dentro de este período definidas mediante la aplicación de puntos de interrupciones o cambios estructurales. En el sur de la región Pampeana, la temperatura y la precipitación presentaron cambios estructurales en los últimos 15 años, lo que expuso a la región al calentamiento y sequedad. La temperatura máxima aumentó $0,5^{\circ} \mathrm{C}$, mientras que la precipitación disminuyó $30 \mathrm{~mm}$. La variabilidad climática a corto plazo nos permitió identificar áreas climáticamente más detalladas y además caracterizar a la región como altamente dependiente de los eventos extremos diarios.

Key words: Short-term climatic variability, climatic sub-regions, trends, structural changes, south of Pampas.

Palabras clave: Variabilidad climática a corto plazo, sub-regiones climáticas, tendencias, cambios estructurales, sur de la Región Pampeana.

Received: 17 August 2018 Accepted: 11 January 2019

*Corresponding author: Federico Ferrelli, Instituto Argentino de Oceanografía (IADOCONICET), Universidad Nacional del Sur, Departamento de Geografía y Turismo, Universidad Nacional del Sur, Departamento de Agronomía, Bahía Blanca (8000), Argentina. E-mail address: fferrelli@criba.edu.ar

\section{Introduction}

The regionalization procedure involves the combination of climate sites with similar precipitation and temperature behavior to obtain coherent sub-regions (Irwin et $a l ., 2017)$. The results provide a comprehensive understanding of local climate patterns across a specific region. On the other hand, a climate regionalization based on short-term climatic variability (i.e., daily thermal and pluviometrical events) by finding the mean state of climate condition at sub-regional scale is essential, mainly in areas exposed to high environmental vulnerability (Shi et al., 2016). Nowadays, in the climate change context, it is relevant to acquire a high accurate climatic regionalization to generate short-term extremes adaptation strategies. At the regional scale, the development 
of a classification that identifies sub-regional differences of climate change becomes essential. Moreover, mapping the extreme rainfall characteristics permitts to assess the spatial distribution of the hazards related to climate events, and thus to support regional planning and environmental management. Moreover, climatic hazard maps, in general, can also be helpful as a part of decision-making systems (Qamar et al., 2017).

It is well known that in most of the world, the temperature increased about $0.7{ }^{\circ} \mathrm{C}$ in the last hundred years (1906-2005), and considering the period 1880-2012, there was observed an increase of $0.85^{\circ} \mathrm{C}$, not only in air temperature but also in ocean surface temperature (IPCC, 2013). Moreover, thermal changes have become much significant after 1970 , with a rate of $0.15^{\circ} \mathrm{C}$ per decade (IPCC, 2013; Worku et al., 2018). At a regional scale, temperature is also increasing in line with global warming (Shahid, 2010, Abatan et al., 2015). For instance, it is noteworthy to mention that all over the world the number of cold days and nights has decreased, while the number of warm days and nights has increased (Song et al., 2014; Salman et al., 2017; Worku et al., 2018). On the other hand, precipitation has not presented a clear spatial pattern worldwide (Chen et al., 2017). However, the amount, intensity, and frequency of very heavy precipitation presented positive trends in most areas around the world (Westra et al., 2013).

Traditionally, global climate changes studies were focused on changes in the monthly or yearly mean values, and there were few studies of daily climate extremes. In the last decades, studies of past climate trends have progressed, especially for precipitation and temperature (Whan et al., 2013; Shrestha et al., 2017). Changes in daily temperatures and rainfall extremes have severe impacts on society by causing property damages, injury, poverty, loss of lives, and biodiversity (IPCC, 2012). Moreover, there were observed changes in the ecosystem structure and function (Tierney et al., 2013). The implication of the rainfall and thermal variability are relevant for areas under stress, such as semiarid regions where thermal and rainfall extremes are common phenomena. These areas are present over $75 \%$ of Argentina's surface and they are often defined as one of the most vulnerable zones due to their environmental changes (Salguero-Gomez et al., 2012; Salman et al., 2017). These extreme events require rigorous risk management and adaptation measures, which demand a detailed understanding of the trend of climate extremes (Worku et al., 2018). Therefore, the study of extreme meteorological events in the short-term, mainly on a daily scale, is essential because it detects the intensity and magnitude of thermal and rainfall variability with high accuracy.

There are seldom studies that explore the daily extreme climatic trends in the south of Pampas. However, there is evidence that the south of Pampas is affected by short-term climate events. For instance, during heat and cold waves, the inhabitants were exposed to discomfort (Ferrelli and Piccolo, 2017) and during heavy and very heavy rains cities have suffered water-logging and floods (Zapperi, 2014). On the other hand, crop yields are affected by temperature extremes such as the delay in the last frost date, as well as heat waves, and by precipitation extremes (Viglizzo, 2018).

On account of the above mentioned, the aim of this study is twofold. Firstly, it contributes to developing a climate regionalization with the analysis of daily temperature and precipitation extremes in the south of the Pampas for the period 1970-2017. Secondly, 
it focuses on analyzing both trends and breakpoints of these events in the different subclimates. In this context, this study identifies the most vulnerable regions to short-term climate variability and provides the necessary information to guide the policies aimed at managing natural resources and agricultural and livestock activities.

\section{Study area}

The study area was the south of Pampas (36 $36^{\circ}-40^{\circ} 44^{\prime} \mathrm{S} ; 63^{\circ} 24^{\prime}-60^{\circ} 30^{\prime}$ $\mathrm{W})$. It is a semiarid region characterized by the occurrence of the most severe floods and droughts over all the Pampas, and it is denominated as the Southwest of Buenos Aires province (Sudoeste Bonaerense) according to the law number 13647 of Buenos Aires province, Argentina (Fig. 1). It has an extension of $65,000 \mathrm{~km} 2$, and a population of 550,000 inhabitants. The effects of daily climate extremes are relevant because most of the area is based on rain-fed agriculture. Moreover, the study area has low adaptive capacity to adverse impacts of climate changes. Its localization exposed this area to a transitional zone between temperate and arid climates, so the regionalization of its climate, considering the daily temperature and precipitation extremes, have key importance in management plans orientation.

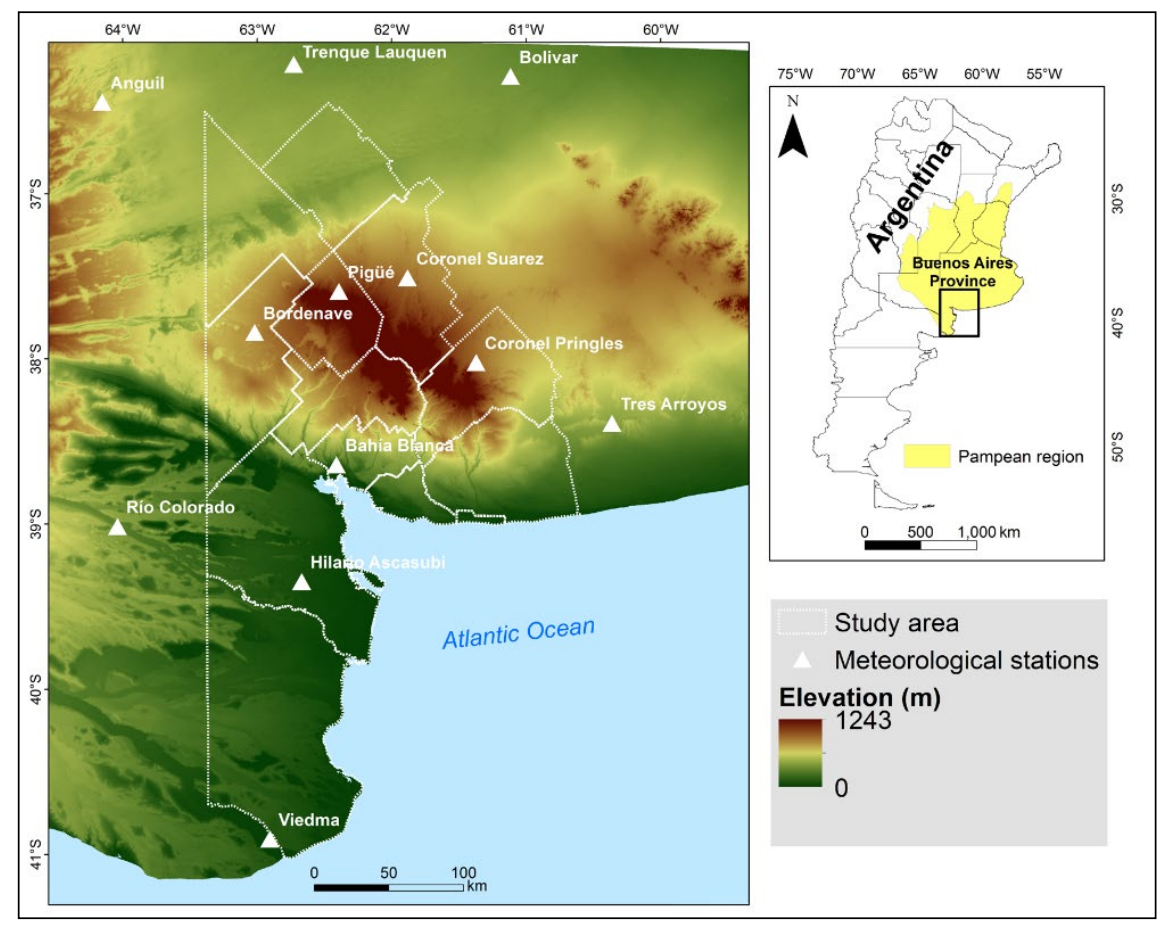

Figure 1. Location map of the south of Pampas (Argentina), the meteorological stations and the elevation. 


\section{Methodology}

The methodology was divided into three steps. The first one included the data collection, the quality, and the homogeneity controls, and the time-series gap-filling. We considered a total of twelve meteorological stations that were equidistantly dispersed over the study area (Fig. 1). The second one included the climate regionalization of the south of the Pampas. We performed a Cluster-based PCA supervised method based on the information of 29 temperature and precipitation extreme indices and elevation. Once we determined the sub-regions, we applied the Ordinary Kriging interpolation method to generate a climatic map (Fig. 2).

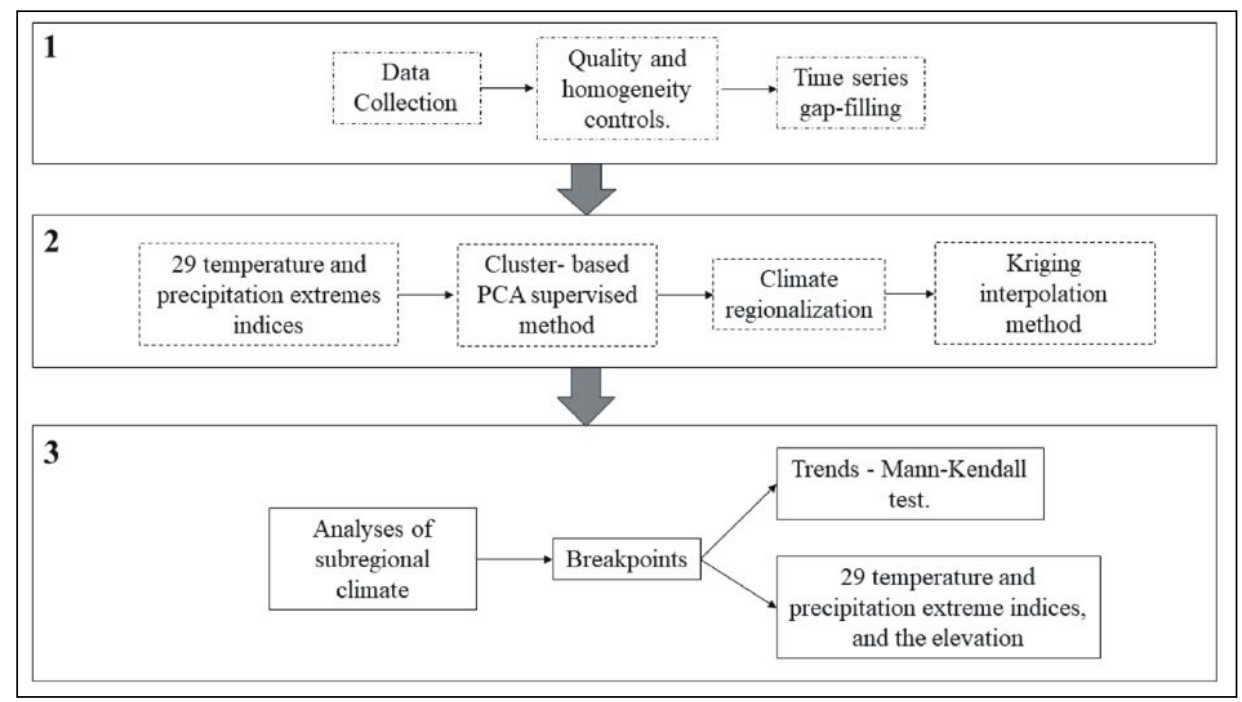

Figure 2. Methodological diagram applied in this study.

The last step was aimed to characterize the climate at a sub-regional scale. In this context, we analyzed the trend of the 29 temperature and precipitation extremes indices for each sub-region during 1970-2017. Moreover, we applied breakpoints to visualize the years when the time series mentioned presented a variance and mean differences. As a result, we obtained two time-series that were studied, and we determined the statistically significant changes with a Kolmogorov-Smirnov test. Finally, we analyzed trends of the climate extreme indices in these both periods (Fig. 2).

\subsection{Data collection}

\subsubsection{In situ data}

Daily minimum (Tmin) and maximum temperature (Tmax), and precipitation (Pp) from twelve meteorological stations with the longest and most complete time-series from the period 1970-2017 were used (Fig. 1, Table 1). These stations belong to the National 
Meteorological Service (SMN, Argentina) and the National Institute of Agricultural Technology (INTA, Argentina).

Table 1. Mean values and standard deviation of each meteorological variable registered in the meteorological stations. Lat.: Latitude, Lon.: Longitude, Tmax: Annual maximum temperature

$\left({ }^{\circ} \mathrm{C}\right)$, Tmin: Annual minimum temperature $\left({ }^{\circ} \mathrm{C}\right)$, Tmean: Annual mean temperature $\left({ }^{\circ} \mathrm{C}\right), \mathrm{Pp}$ :

Annual precipitation (mm), E. Elevation (m), MD. Missing data (\%), and O. Outliers (\%).

\begin{tabular}{|l|r|r|r|r|r|r|r|r|l|}
\hline \multicolumn{1}{|c|}{ Station name } & \multicolumn{1}{c|}{ Lat. } & \multicolumn{1}{c|}{ Lon. } & \multicolumn{1}{c|}{ Tmax } & \multicolumn{1}{c|}{ Tmin } & \multicolumn{1}{c|}{ Tmean } & \multicolumn{1}{c|}{ Pp } & \multicolumn{1}{l|}{ E. } & \multicolumn{1}{l}{ MD } & O \\
\hline Trenque Lauquen & -35.97 & -62.74 & $21.8 \pm 0.6$ & $8.8 \pm 0.6$ & $15.3 \pm 0.5$ & $889 \pm 186$ & 95 & 4.89 & 0.73 \\
\hline Bolivar & -36.25 & -61.1 & $21.9 \pm 0.7$ & $9.1 \pm 0.8$ & $15.4 \pm 0.6$ & $975 \pm 197$ & 93 & 2.11 & 0.12 \\
\hline Anguil & -36.51 & -64.01 & $22.7 \pm 0.7$ & $7.8 \pm 0.7$ & $15.3 \pm 0.6$ & $770 \pm 140$ & 165 & 2.32 & 0.06 \\
\hline Coronel Suárez & -37.5 & -61.95 & $20.4 \pm 0.6$ & $7.2 \pm 0.6$ & $13.8 \pm 0.6$ & $785 \pm 188$ & 234 & 2.17 & 0.22 \\
\hline Pigïé & -37.6 & -62.38 & $20 \pm 0.8$ & $7.6 \pm 0.4$ & $14.8 \pm 0.4$ & $780 \pm 180$ & 304 & 1.32 & 0.21 \\
\hline Bordenave & -37.85 & -63.02 & $21.8 \pm 1$ & $8.1 \pm 0.7$ & $14.9 \pm 0.7$ & $708 \pm 186$ & 212 & 1.02 & 0.14 \\
\hline Coronel Pringles & -38.02 & -61.33 & $20.8 \pm 0.6$ & $7.1 \pm 0.5$ & $14 \pm 0.5$ & $778 \pm 176$ & 247 & 4.22 & 0.56 \\
\hline Tres Arroyos & -38.38 & -60.27 & $20.8 \pm 0.6$ & $7.8 \pm 0.6$ & $14.3 \pm 0.5$ & $782 \pm 145$ & 108 & 0.92 & 0.09 \\
\hline Bahía Blanca & -38.73 & -62.17 & $22 \pm 0.5$ & $9.1 \pm 0.5$ & $15.6 \pm 0.5$ & $631 \pm 140$ & 83 & 3.25 & 0.18 \\
\hline Río Colorado & -39.02 & -64.08 & $22.1 \pm 0.6$ & $7.6 \pm 0.7$ & $14.9 \pm 0.5$ & $462 \pm 102$ & 79 & 4.68 & 0.19 \\
\hline Hilario Ascasubi & -39.38 & -62.62 & $21.9 \pm 0.5$ & $7.9 \pm 0.6$ & $14.9 \pm 0.4$ & $496 \pm 100$ & 22 & 1.77 & 0.17 \\
\hline Viedma & -40.85 & -63.02 & $21.7 \pm 0.7$ & $7.7 \pm 0.5$ & $14.7 \pm 0.5$ & $364 \pm 113$ & 7 & 0.34 & 0.02 \\
\hline
\end{tabular}

The times series were pre-processed by including table organization with columns that contained daily maximum and minimum temperature $\left({ }^{\circ} \mathrm{C}\right)$ and precipitation $(\mathrm{mm}$ day 1). Moreover, the mask value that represented "NoData" was identified as -99.9. During the re-formatting and conversion steps, some topographical errors, the inconsistency of NoData mask, and mislabeling were corrected with automatic scripts (Zhou et al., 2018). Finally, the resulting files were manually checked to avoid all the possible errors in the processing methods.

\subsubsection{Quality control and homogeneity tests}

We implemented a data quality control and a homogeneity assessment by using RClimDex software (Zhang and Yang, 2013) and RHtests V4 software (Wang et al., 2010), respectively. Both were freely available from the Expert Team on Climate Change Detection and Indices (ETCCDI) website http://etccdi.pacificclimate.org. Before indices calculation (described in section 2.2.1), we applied technical and critical control with the RClimDex Software. Moreover, temporal homogeneity of daily data from the twelve meteorological stations was carried out with RHTest V4 software package, based on the penalized maximal $t$-test (Wang et al., 2007) and the penalized maximal $F$-test (Wang, 2008a) set in a recursive algorithm (Wang, 2008b; Ruml et al., 2016). 
Climatic homogenization was aimed to adjust observation, considering that the temporal changes in the corrected data were a consequence of variation only in climate. The not-climate factors were composed of changes in the station location, environment, instrumentation that could affect the real trends in data (Ruml et al., 2016). The results of the homogeneity test, resulting in missing data and outliers, are presented in Table 1.

\subsubsection{Time series gap-filling}

The gap-filling method was developed with a Principal Component Analysis (PCA) (described in section 3.3.1). This method has been widely used to gap-fill the climate time series (Taylor et al., 2013; Kondrashov et al., 2014; Zhou et al., 2018), and allowed for generating a new set of variables as a linear combination of the original variables, capturing most of the observed variance in the original data.

We calculated the initial guess values from linear models between each station and its neighboring one. NoData, outliers and duplicated values were calculated as the weighted mean of estimated values from the simple linear models. Afterward, truncated PCA with a defined number of a factor was applied and subsequently, an inverse PCA was performed with these resultant values to create a generalized representation of the input datasets.

Finally, we calculated the differences between the estimation in the current iteration and the previous one, following the methodology described by Zhou et al. (2018). We filled the incomplete series with a value lower than $0.1^{\circ} \mathrm{C}$ for temperature and $0.9 \mathrm{~mm}$ for precipitation in all the meteorological stations analyzed (Table 1).

\subsection{Climate regionalization analyses}

\subsubsection{Extreme indices calculation}

The Expert Team on Climate Change Detection and Indices (ETCCDI) has defined a set of 27 extreme indices composed by 16 temperature-related indices and 11 precipitation-related indices. These provide a comprehensive overview of temperature and precipitation statistics (Peterson et al., 2001). They were reviewed by Zhang et al. (2011) and were composed by percentile-based, absolute, duration, and threshold indices, that have been widely used worldwide (Zhou et al., 2016; Chen et al., 2017). Moreover, we added Tmaxmean and Tminmean as two indices that complemented this section. Therefore, we used a total of 29 climatic indices and the elevation.

These indices were calculated from the daily maximum and minimum temperatures and the precipitation from the twelve meteorological stations by using RClimDex software (Zhang and Yang, 2013) (Table 2). The indices were split into four categories. Considering the definition (see Table 2) we subdivided the temperature indices into three groups: (i) Hot extreme indices, (ii) Cold extreme indices, (iii) User-defined (Table 2), while the rainfall indices were identified as (iv) Precipitation extremes indices (Table 2).

On the other hand, the information derived from these indices was utilized to generate a climatic regionalization by applying a cluster-based PCA supervised method (described in section 2.2.2). 
Table 2. Temperature and precipitation extreme indices. Modified from Peterson et al. (2001) and Rulm et al. (2017).

\begin{tabular}{|c|c|c|c|c|}
\hline ID & & \begin{tabular}{|c|c|}
$\begin{array}{c}\text { Descriptive } \\
\text { name }\end{array}$ \\
\end{tabular} & Definition & Units \\
\hline & \multicolumn{4}{|c|}{ User-defined } \\
\hline 1 & Tmax & $\begin{array}{l}\text { Maximum tem- } \\
\text { perature }\end{array}$ & Daily maximum temperature. & ${ }^{\circ} \mathrm{C}$ \\
\hline \multirow[t]{2}{*}{2} & Tmin & $\begin{array}{l}\text { Minimum tem- } \\
\text { perature }\end{array}$ & Daily minimum temperature. & ${ }^{\circ} \mathrm{C}$ \\
\hline & \multicolumn{4}{|c|}{ Hot extremes } \\
\hline 3 & $\mathrm{TXx}$ & Hottest day & $\begin{array}{l}\text { The minimum monthly value of the daily maximum } \\
\text { temperature. }\end{array}$ & ${ }^{\circ} \mathrm{C}$ \\
\hline 4 & $\mathrm{TNX}$ & Hottest night & $\begin{array}{l}\text { The maximum monthly value of the daily minimum } \\
\text { temperature. }\end{array}$ & ${ }^{\circ} \mathrm{C}$ \\
\hline 5 & TX90p & Warm days & Days' percentage when $\mathrm{TX}>90^{\text {th }}$ percentile. & days \\
\hline 6 & TN90p & Warm nights & Days' percentage when $\mathrm{TN}>90^{\text {th }}$ percentile. & days \\
\hline 7 & SU25 & Summer days & Annual count when TX (daily maximum) $>25^{\circ} \mathrm{C}$. & days \\
\hline 8 & TR20 & \begin{tabular}{|l|} 
Tropical Nights \\
\end{tabular} & Annual count when TN (daily minimum) $>20^{\circ} \mathrm{C}$ & days \\
\hline 9 & WSDI & \begin{tabular}{|l|} 
Warm spell dura- \\
tion indicator
\end{tabular} & $\begin{array}{l}\text { Annual count of days with at least six consecutive days } \\
\text { when TX }>90^{\text {th }} \text { percentile. }\end{array}$ & days \\
\hline & \multicolumn{4}{|c|}{ Cold extremes } \\
\hline 10 & TXn & Coldest days & $\begin{array}{l}\text { The minimum monthly value of the daily maximum } \\
\text { temperature. }\end{array}$ & ${ }^{\circ} \mathrm{C}$ \\
\hline 11 & TNn & Coldest night & $\begin{array}{l}\text { The minimum monthly value of the daily minimum } \\
\text { temperature. }\end{array}$ & ${ }^{\circ} \mathrm{C}$ \\
\hline 12 & TX10p & Cold days & Days' percentage when $\mathrm{TX}<10^{\text {th }}$ percentile. & days \\
\hline 13 & TN10p & Cold nights & Days' percentage when $\mathrm{TN}<10^{\text {th }}$ percentile. & days \\
\hline 14 & FD0 & Frost days & Annual count when TN (daily minimum) $<0^{\circ} \mathrm{C}$. & days \\
\hline 15 & ID0 & Ice days & Annual count when TX (daily maximum) $<0^{\circ} \mathrm{C}$. & days \\
\hline 16 & CSDI & \begin{tabular}{|l|} 
Cold spell dura- \\
tion indicator
\end{tabular} & $\begin{array}{l}\text { Annual count of days with at least six consecutive days } \\
\text { when } \mathrm{TN}<10^{\text {th }} \text { percentile. }\end{array}$ & days \\
\hline & \multicolumn{4}{|c|}{ Others temperature indices } \\
\hline 17 & GSL & $\begin{array}{l}\text { Growing season } \\
\text { length }\end{array}$ & $\begin{array}{l}\text { Annual }\left(1^{\text {st }} \text { Jan to } 31^{\text {st }} \text { Dec in North Hemisphere, } 1^{\text {st }}\right. \\
\text { July to } 30^{\text {th }} \text { June in South Hemisphere) count between } \\
\text { the first span of at least six days with Tmean }>5{ }^{\circ} \mathrm{C} \text { and } \\
\text { first span after } 1 \text { July ( } 1 \text { January in SH) of } 6 \text { days with } \\
\text { Tmean }<5^{\circ} \mathrm{C} \text {. }\end{array}$ & days \\
\hline 18 & DTR & $\begin{array}{l}\text { Diurnal tempera- } \\
\text { ture range }\end{array}$ & The monthly mean difference between TX and TN. & ${ }^{\circ} \mathrm{C}$ \\
\hline & \multicolumn{4}{|c|}{ Precipitation extremes } \\
\hline 19 & RX1day & $\begin{array}{l}\text { Max. 1-day pre- } \\
\text { cipitation amount }\end{array}$ & Monthly maximum 1-day precipitation. & $\mathrm{mm}$ \\
\hline 20 & RX5day & $\begin{array}{l}\text { Max. 5-day pre- } \\
\text { cipitation amount }\end{array}$ & Monthly maximum consecutive 5-day precipitation. & $\mathrm{mm}$ \\
\hline 21 & SDII & $\begin{array}{l}\text { Simple daily } \\
\text { intensity index }\end{array}$ & $\begin{array}{l}\text { Annual total precipitation divided by the number of wet } \\
\text { days (defined as PRCP }>1 \mathrm{~mm} \text { ) in the year. }\end{array}$ & $\begin{array}{c}\mathrm{mm} / \\
\text { day }\end{array}$ \\
\hline 22 & R10 & $\begin{array}{l}\text { Heavy precipita- } \\
\text { tion days }\end{array}$ & Annual count of days when PRCP $>10 \mathrm{~mm}$ & days \\
\hline 23 & R20 & $\begin{array}{l}\text { Very heavy pre- } \\
\text { cipitation days }\end{array}$ & Annual count of days when PRCP $>20 \mathrm{~mm}$. & days \\
\hline
\end{tabular}




\begin{tabular}{|l|l|l|l|c|}
\hline ID & & \multicolumn{1}{|c|}{$\begin{array}{c}\text { Descriptive } \\
\text { name }\end{array}$} & \multicolumn{1}{|c|}{ Definition } & Units \\
\hline $\mathbf{2 4}$ & Rnn & $\begin{array}{l}\text { Number of days } \\
\text { above nn mm }\end{array}$ & $\begin{array}{l}\text { Annual count of days when PRCP }>\mathrm{nn} \mathrm{mm}, \mathrm{nn} \text { is a } \\
\text { user-defined threshold. }\end{array}$ & days \\
\hline $\mathbf{2 5}$ & CDD & $\begin{array}{l}\text { Consecutive dry } \\
\text { days }\end{array}$ & $\begin{array}{l}\text { A maximum number of consecutive days with RR }< \\
1 \mathrm{~mm} .\end{array}$ & days \\
\hline $\mathbf{2 6}$ & CWD & $\begin{array}{l}\text { Consecutive wet } \\
\text { days }\end{array}$ & $\begin{array}{l}\text { A maximum number of consecutive days with RR }> \\
1 \mathrm{~mm} .\end{array}$ & days \\
\hline $\mathbf{2 7}$ & R95p & Very wet days & Annual total PRCP when RR $>95^{\text {th }}$ percentile. & $\mathrm{mm}$ \\
\hline $\mathbf{2 8}$ & R99p & $\begin{array}{l}\text { Extremely wet } \\
\text { days }\end{array}$ & Annual total PRCP when $\mathrm{RR}>99^{\text {th }}$ percentile. & $\mathrm{mm}$ \\
\hline $\mathbf{2 9}$ & $\begin{array}{l}\text { PRCP- } \\
\text { TOT }\end{array}$ & $\begin{array}{l}\text { Annual total wet- } \\
\text { day precipitation }\end{array}$ & Annual total PRCP in wet days $(\mathrm{RR}>1 \mathrm{~mm})$. & $\mathrm{mm}$ \\
\hline
\end{tabular}

\subsubsection{Cluster-based PCA supervised analysis}

We applied a Principal Component Analysis (PCA) for dimension reduction. In this case, we applied PCA over the 29 climate indices for the twelve meteorological stations and the elevation to generate a correlation matrix and to create Principal Factors (PC). PCA applies an orthogonal transformation to convert a set of information of possibly correlated variables into a set of values of linear and uncorrelated variables called PC (O'Rourke et al., 2013; Lu et al., 2017). We utilized a Spearman matrix to organize the data and to detect the correlation between climate indices and elevation. An individual PC represents a linear combination of optimally-weighted observed variables. The number of PC is less than or equal to the number of original variables (Lu et al., 2017).

To perform the regionalization of the climate of the south of the Pampas, we considered a cluster-based PCA that extend PCA by including unsupervised (K-means) or supervised (agglomerative, hierarchical) clustering of the PC. In this context, we applied a cluster with a Ward hierarchical method, and we define an interval of Euclidean distance rescaled as a dissimilarity measurement. The purpose of clustering is the statistical classification of individual objects into groups or clusters. The criterion for grouping is the similarity or dissimilarity. The PCs were the objects to be grouped according to each meteorological station. In the literature, this method demonstrated to be the best fit for climatic studies (Marzban and Sandgathe, 2005; Lu et al., 2017, among others).

We considered that the classes or groups were set when the initial unit values reach their dissimilarity by up to $2 \%$. We measured the distance between stations and formed groups by joining them according to the increase in the total amount of the sum of squares of the differences of each group to the centroid of each group. This method was calculated with the following equation:

$$
E_{k}=\sum_{i=1}^{n k} \sum_{j=1}^{n}\left(X_{i j}^{k}-m_{j}^{k}\right)^{2}=\sum_{i=1}^{n k} \sum_{j=1}^{n}\left(X_{i j}^{k}\right)^{2}-n_{k} \sum_{j=1}^{n}\left(m_{j}^{k}\right)^{2}
$$

where $j$ is the variable, $i$ is the individual and $k$ is the cluster. $\mathrm{E} k$ is the sum of squared errors of cluster $k$, which represents the squared Euclidean distance between each cluster $k$ to its centroid. 


$$
E=\sum_{k=1}^{h} E_{k}
$$

where $E$ is the sum of squared errors for all clusters if we assume that $h$ clusters are presented.

The optimal number of clusters was selected considering the Elbow method. Thus, the mean distance of each element (in this case, the stations) to the centroid was calculated. Afterward, we graphed the changes in the distance linearly until these cease to be significant. This method allowed us to determine that four clusters represented the optimal number to be applied in the study area.

\subsubsection{Regionalization mapping}

Once the regionalization was done, we designed a climatic map, utilizing a Geographical Information System (GIS) (ArcGIS 10.2) to interpolate. We used the Ordinary Kriging method that has been widely used worldwide (e.g., Berndt and Haberlandt, 2018). This method assumes that the distance of sample points reflects a spatial correlation that can be used to explain variation in some area. It fits a function to a specified number of points or all points within a specified radius to determine the output value for each location. Kriging aims at producing a better linear unbiased estimate for an unknown location (Aliaga et al., 2017). It is linear because the projected values are weighted linear combinations of the available data, and unbiased because the mean of the error is 0 ; it aims to minimize the variance of the errors (Menafoglio et al., 2013). This technique assumes that there is no constant mean for the data over an area (i.e., no trend).

\subsection{Sub-regional climate analyses}

\subsubsection{Trend's analyses}

We utilized a linear regression method and the Mann-Kendall test (Mann, 1945; Kendall 1975) to estimate the trend with an $\alpha=0.05$. This test uses the Tau-b statistics of Kendall. If it is positive, then the data series has a positive trend and vice versa. The trend was considered significant when the p-value $<0.05$. On the other hand, we quantified the trend with the Sen estimator (1968), following the next equation:

$$
f_{(t)}=B+Q * t
$$

where $Q$ is the slope, $B$ is a constant and $t$ is the time. To obtain the $\mathrm{Q}$ value, we calculated all the slopes considering a pair of data, following the next equation:

$$
\mathrm{Q}_{\mathrm{i}}=\frac{\mathrm{x}_{\mathrm{i}}-\mathrm{x}_{\mathrm{k}}}{j-k} ; \mathrm{i}=1,2, \ldots, \mathrm{n}
$$

where $x i$ and $x k$ are the data over the time $j$ and $\mathrm{k}(j>k)$, respectively. If there are $\mathrm{n}$ values over the time-series, there will be as many as slopes estimated. $Q i$. The median of $N$ values is the Sen estimator (Sen, 1968). 


\subsubsection{Detection of temperature and precipitation structural changes}

To evaluate the temporal variation in the climate of the south of Pampas, we applied breakpoints over the time series of maximum and minimum temperatures, and rainfall for each climatic sub-region for the period 1970-2017. We employed these variables because they are the input data to calculate the 29 extremes indices. We identified shifts in the linear trend of the time series. Then, we applied piecewise linear breakpoints to recognize any significant fluctuations in the mean and variance by using the Strucchange package of R-Studio software. The identification of the segments allowed us to split the time-series. The number of breakpoints was set, so that the confidence intervals of the different points did not overlap (Abbate et al., 2017).

This type of analysis is common in meteorology because it establishes dissimilarities within the time series. In this context, we determined two-time series or sub-periods (A and B) for each variable: the first starts in 1970 and it finishes in the year of change (breakpoint) and the second one starts in the breakpoint year and finishes in 2017. Afterward, we calculated the trends of extreme climate indices for each sub-period (Table 2). Moreover, both sets were compared with a two-tailed Kolmogorov-Smirnov test at $95 \%$ significance level.

\section{Results}

\subsection{Climatic regionalization}

The PCA analysis permitted to dimension reduction and to extract information from the 29 indices calculated from the twelve meteorological stations over all the study area and the elevation. As a result, we identified seven factors that explained the $96.6 \%$ of the variance (Table 3). Moreover, we created the Matrix of Principal Components (Table 4).

Table 3. Principal Factors (PCs) obtained from the PCA applied to 29 climate indices from each meteorological station.

\begin{tabular}{|l|r|r|r|r|r|r|}
\hline \multirow{3}{*}{ PCs } & \multicolumn{3}{|c|}{ Eigenvalues } & \multicolumn{3}{c|}{ Total variance } \\
\cline { 2 - 8 } & \multicolumn{1}{|c|}{ Total } & $\begin{array}{c}\text { \% vari- } \\
\text { ance }\end{array}$ & \% accumulate & Total & $\begin{array}{c}\text { \% de vari- } \\
\text { ance }\end{array}$ & \% accumulate \\
\hline 1 & 11.700 & 40.344 & 40.344 & 11.700 & 40.344 & 40.344 \\
\hline 2 & 6.313 & 21.770 & 62.113 & 6.313 & 21.770 & 62.113 \\
\hline 3 & 4.052 & 13.973 & 76.087 & 4.052 & 13.973 & 76.087 \\
\hline 4 & 1.956 & 6.744 & 82.831 & 1.956 & 6.744 & 82.831 \\
\hline 5 & 1.516 & 5.227 & 88.058 & 1.516 & 5.227 & 88.058 \\
\hline 6 & 1.321 & 4.557 & 92.615 & 1.321 & 4.557 & 92.615 \\
\hline 7 & 1.159 & 3.995 & 96.610 & 1.159 & 3.995 & 96.610 \\
\hline 8 & .390 & 1.345 & 97.955 & & & \\
\hline 9 & .359 & 1.237 & 99.192 & & & \\
\hline 10 & .150 & .517 & 99.709 & & & \\
\hline 11 & .084 & .291 & 100 & & & \\
\hline
\end{tabular}


Table 4. Matrix of Principal Components.

\begin{tabular}{|l|r|r|r|r|r|r|r|}
\hline & \multicolumn{1}{|c|}{$\mathbf{1}$} & \multicolumn{1}{c|}{$\mathbf{2}$} & \multicolumn{1}{c|}{$\mathbf{3}$} & \multicolumn{1}{c|}{$\mathbf{4}$} & \multicolumn{1}{c|}{$\mathbf{5}$} & \multicolumn{1}{c|}{$\mathbf{6}$} & \multicolumn{1}{c|}{$\mathbf{7}$} \\
\hline PRCPTOT & .988 & .054 & -.046 & .070 & -.068 & .051 & .073 \\
\hline R10 & .988 & .024 & -.050 & .100 & -.066 & .053 & .023 \\
\hline R20 & .985 & .038 & .028 & .047 & -.049 & .053 & .137 \\
\hline R95p & .985 & .053 & -.058 & .046 & -.067 & -.089 & .013 \\
\hline Rnn & .978 & .093 & .066 & -.018 & -.064 & .025 & .146 \\
\hline R99p & .941 & -.056 & -.022 & .100 & -.077 & -.030 & -.281 \\
\hline Rx1day & .940 & .120 & .208 & -.169 & -.166 & -.057 & -.003 \\
\hline Rx5day & .932 & .137 & .188 & -.163 & -.150 & -.133 & .103 \\
\hline SDII & .910 & .088 & .234 & -.183 & .008 & -.002 & .260 \\
\hline CSDI & .769 & -.119 & .422 & .186 & .334 & .118 & -.134 \\
\hline TXx & -.701 & .482 & .400 & .088 & .274 & .005 & -.128 \\
\hline Tminmean & .628 & .504 & .073 & -.007 & .550 & .130 & -.122 \\
\hline CWD & .601 & .041 & .083 & .429 & -.373 & .429 & -.304 \\
\hline FD0 & -.213 & -.790 & .459 & .029 & -.024 & -.001 & .300 \\
\hline Elevation & .547 & -.769 & .105 & -.124 & .049 & -.042 & -.062 \\
\hline TNx & -.353 & .757 & .260 & .055 & .369 & .199 & -.113 \\
\hline WSDI & .484 & .737 & -.191 & -.071 & .239 & -.005 & .227 \\
\hline TN10p & -.107 & -.723 & -.014 & .531 & .077 & -.334 & -.087 \\
\hline GSL & .002 & -.721 & .454 & -.394 & .175 & -.028 & -.230 \\
\hline TXn & -.496 & .709 & .143 & .384 & -.184 & -.037 & .186 \\
\hline Tmaxmean & -.209 & .668 & .483 & .431 & -.187 & -.151 & .119 \\
\hline TN90p & -.068 & -.576 & -.227 & .508 & .279 & .063 & .359 \\
\hline TR20 & -.091 & -.160 & .794 & .139 & -.148 & .096 & -.491 \\
\hline CDD & -.447 & -.134 & .737 & -.252 & -.142 & .170 & .293 \\
\hline TNn & .159 & .609 & -.696 & -.138 & .133 & .013 & -.198 \\
\hline SU25 & .010 & .631 & .695 & .146 & -.223 & .069 & .111 \\
\hline DTR & .434 & -.220 & .579 & .165 & .565 & .045 & .138 \\
\hline TX10p & .104 & -.440 & -.475 & .568 & .027 & .375 & .032 \\
\hline TX90p & .200 & .120 & .290 & .064 & -.837 & -.138 \\
\hline
\end{tabular}

Afterward, we employed these factors in a supervised cluster analysis. This method evidenced the existence of four groups or climatic sub-regions in the study area. The meteorological stations presented high similarity, and they were grouped up considering a Euclidean distance rescaled (Fig. 3). Subsequently, the objects (or meteorological stations) were named considering the Cardinal points. From north to south, we denominated as: i) North, ii) Northeast, iii) Center, and iv) South (Fig. 4). 


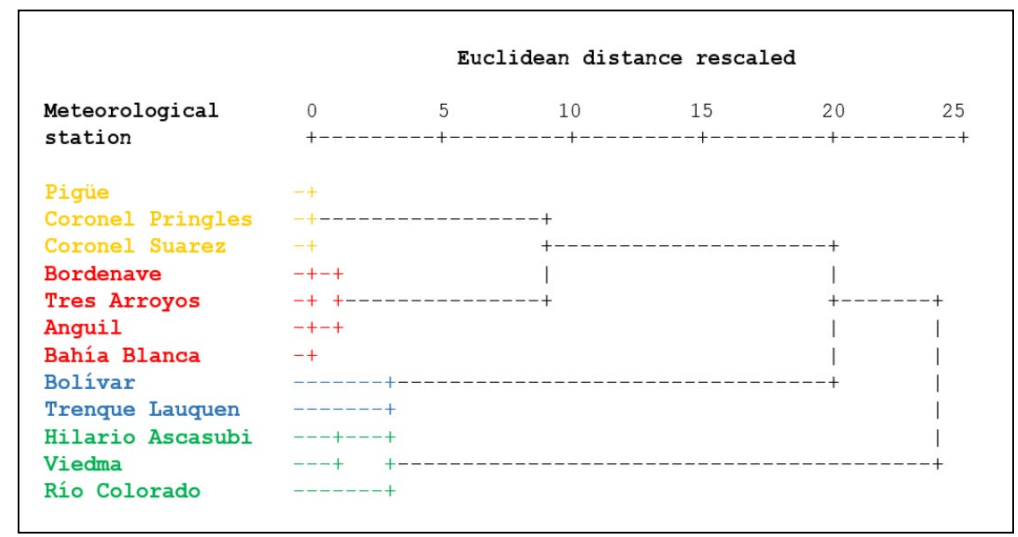

Figure 3. Groups obtained from cluster analysis.

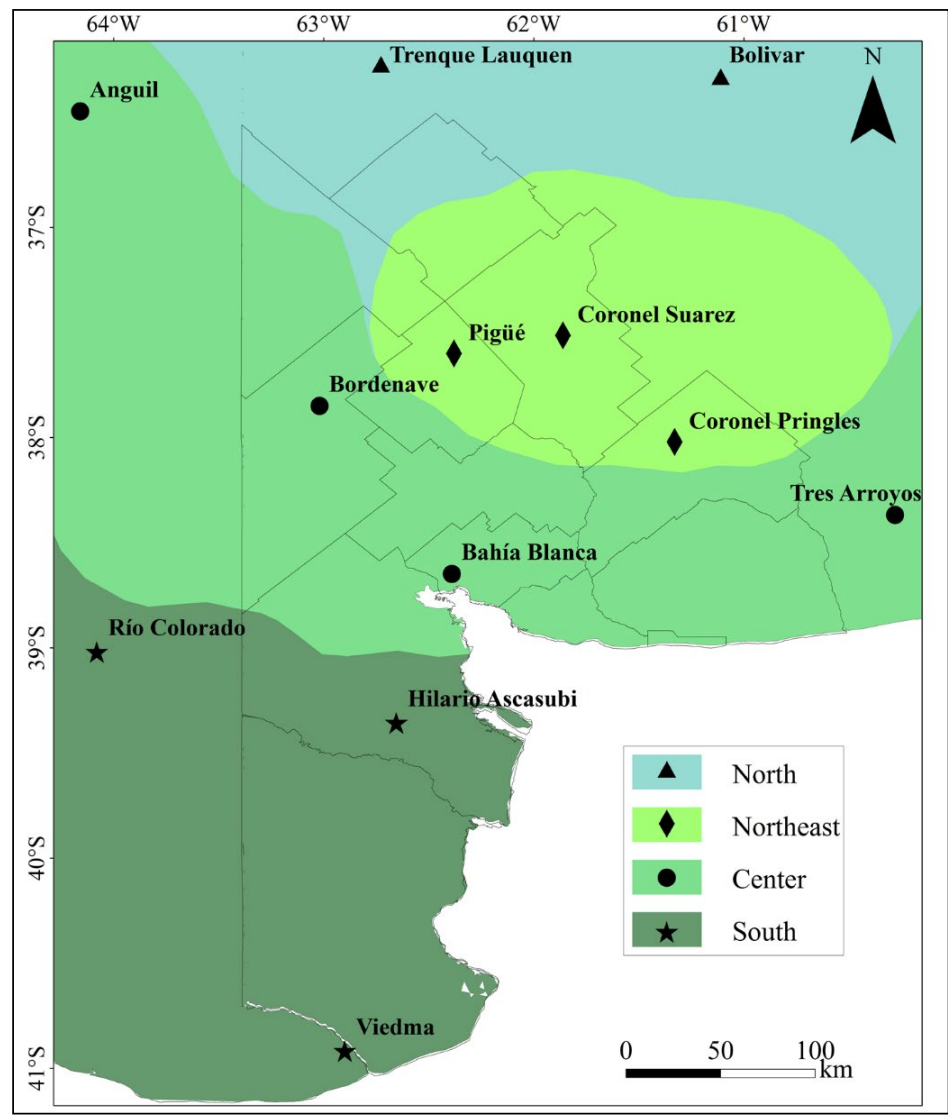

Figure 4. Spatial distribution of the climatic sub-regions in the southern Pampas based on the analysis of daily extreme climate indices during the period 1970-2017. 
All sub-regions presented a similar rainfall and thermal regime. The rainfall was concentrated in autumn (February, March, and April) and spring (October, November, and December), while the temperature was characterized by high values during the summer and low ones during the winter (Fig. 5). From the delimitation of the climate in the south of the Pampas, it determined that the Sub-region North present the highest annual precipitation (> $900 \mathrm{~mm}_{\text {year }}{ }^{-1}$ ), and temperatures. The annual maximum temperature was $21.9^{\circ} \mathrm{C}$ and the minimum $9.1^{\circ} \mathrm{C}$. On the other hand, the sub-region Northeast recorded $795 \mathrm{~mm}$ rainfall per year, whereas $730.7 \mathrm{~mm}_{\text {year }}{ }^{-1}$ in the Center. However, these two climatic sub-regions had a different thermal pattern. The former is the coldest throughout the area (with an annual minimum temperature of $7.4^{\circ} \mathrm{C}$, and a maximum of $20.3^{\circ} \mathrm{C}$ ). Finally, the sub-region South was the driest (430 mm year ${ }^{-1}$ ), and the thermal behavior was similar to the Center (Fig. 5).

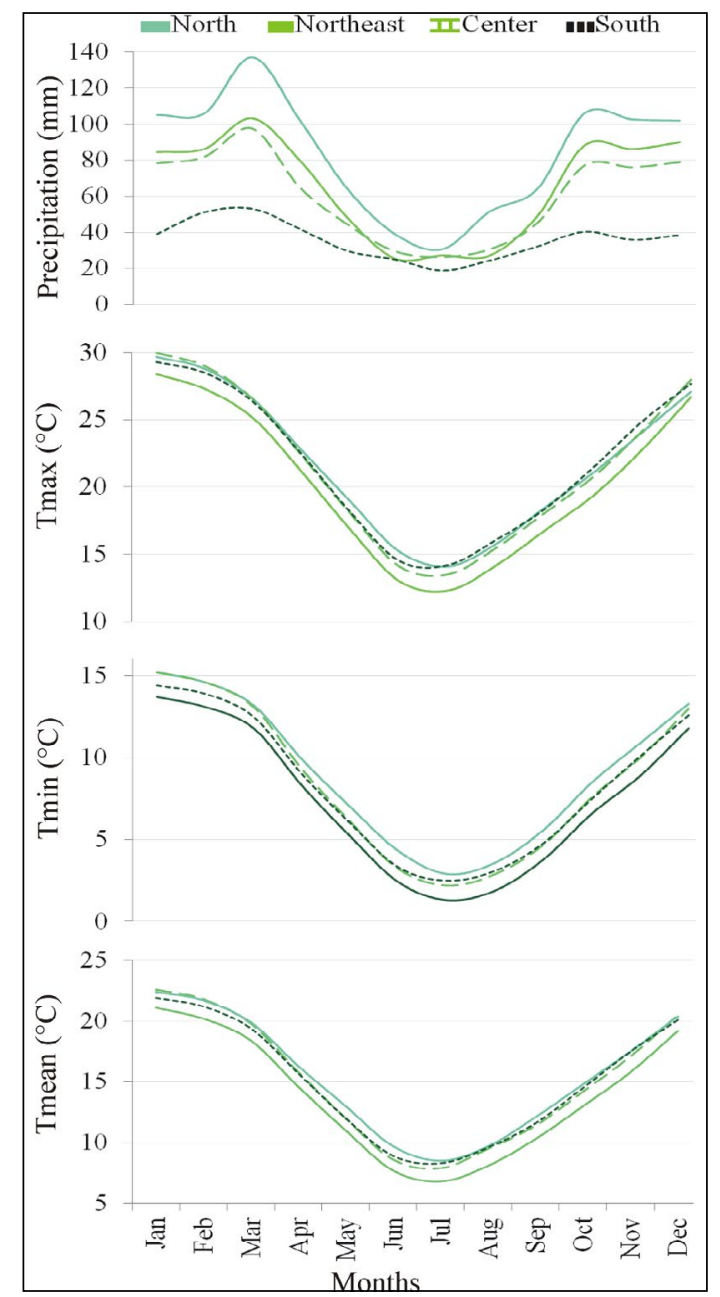

Figure 5. Monthly Precipitation, Maximum temperature, Minimum temperature, and Mean temperature of each climatic sub-region (North, Northeast, Center, and South). 


\subsection{Trends of daily climatic extremes during 1970-2017}

The daily temperature and precipitation extremes had a significant variation during the period 1970-2017. North was the only sub-region with a negative trend in minimum temperature (Tminmean), recording $-1.4^{\circ} \mathrm{C} / 47$ years, while maximum had a positive trend. Moreover, cold extremes such as frost days (FD0), and cold nights (Tn10p) increased (18.8 days and 6.1 days/47 years, respectively) (Table 2). Generally, hot extremes had registered negative trend with statically variation in TN90p (-5.9 days/47 years). Summer days (SU25) presented a positive trend, increasing about 15.1 days/47 years. The same pattern was observed when it was analyzed precipitation except for Rx5day (-10.2 mm/47 years) (Table 5).

Table 5. Extreme climate indices' slopes in each climatic sub-region during the period 19702017. The * indicates statistical significance at $95 \%$.

\begin{tabular}{|c|c|c|c|c|c|}
\hline Indices & Units & North & Northeast & Center & South \\
\hline \multicolumn{6}{|c|}{ User Defined and DTR } \\
\hline Tmaxmean & ${ }^{\circ} \mathrm{C} /$ period & 0.2 & 0.4 & 0.5 & 0.3 \\
\hline Tminmean & ${ }^{\circ} \mathrm{C} /$ period & $-1.4 *$ & 0.3 & $0.8 *$ & $0.9^{*}$ \\
\hline DTR & ${ }^{\circ} \mathrm{C} /$ period & $1.4 *$ & 0.8 & -0.3 & $-0.5^{*}$ \\
\hline \multicolumn{6}{|c|}{ Hot Extremes } \\
\hline TNX & ${ }^{\circ} \mathrm{C} /$ period & -0.5 & $1.1 *$ & $1 *$ & 0.4 \\
\hline TXX & ${ }^{\circ} \mathrm{C} /$ period & -0.4 & 0.4 & -0.3 & 0.2 \\
\hline TX90p & days/period & -0.7 & 2.6 & 1.9 & 0.1 \\
\hline TN90p & days/period & $-5.9 *$ & -0.4 & 1.5 & $3.4 *$ \\
\hline SU25 & days/period & 15.1 & 10.1 & $16.4 *$ & 3.7 \\
\hline TR20 & days/period & -1.4 & 0 & 1.8 & 2.2 \\
\hline WSDI & days/period & 0 & 0 & 0 & 0 \\
\hline \multicolumn{6}{|c|}{ Cold Extremes } \\
\hline TXn & ${ }^{\circ} \mathrm{C} /$ period & -0.1 & 0.3 & $1.2 *$ & 0.5 \\
\hline $\mathrm{TNn}$ & ${ }^{\circ} \mathrm{C} /$ period & $-2.3^{*}$ & -1.2 & 2.3 & 0.8 \\
\hline TX10p & days/period & -2.6 & -2.1 & -3.6 & -2.5 \\
\hline TN10p & days/period & $6.1 *$ & $2.9 *$ & $-5.8 *$ & $-5.1 *$ \\
\hline FD0 & days/period & $18.8^{*}$ & $8.5 *$ & $-13.7 *$ & $-13.8^{*}$ \\
\hline ID0 & days/period & 0 & 0 & 0 & 0 \\
\hline CSDI & days/period & 0 & 0 & 0 & 0 \\
\hline \multicolumn{6}{|c|}{ Precipitation Extremes } \\
\hline Rx1day & $\mathrm{mm} /$ period & 6.8 & 4.8 & -11.7 & $-12.1 *$ \\
\hline Rx5day & $\mathrm{mm} /$ period & -10.2 & 15.2 & -4 & -3.4 \\
\hline SDII & $\mathrm{mm} /$ period & 1.2 & 0.2 & -0.11 & 0.2 \\
\hline $\mathrm{R} 10$ & days/period & 0 & 0 & 0 & 2.1 \\
\hline R20 & days/period & 1.9 & 0 & 0 & 0 \\
\hline Rnn & days/period & 0 & 0 & 0 & 0 \\
\hline R95p & $\mathrm{mm} /$ period & 32.9 & -7.5 & -23.6 & -14.1 \\
\hline R99p & $\mathrm{mm} /$ period & 0 & 0 & 0 & 0 \\
\hline PRCPTOT & $\mathrm{mm} /$ period & 53.1 & 63.7 & -16.9 & 19.1 \\
\hline
\end{tabular}


The Northeast had a tendency to warming with both Tminmean and Tmaxmean with positive trends. Hot and cold extremes were mainly positive with statistically significant changes in $\mathrm{TNx}\left(1.1^{\circ} \mathrm{C} / 47\right.$ years) for the former and FD0 and TN10p (8.5 and 2.9 , respectively) for the latter (Table 5). Precipitation extremes had a positive trend but without statistically significant variations. However, PRCPTOT registered the maximum increase of all over the region $(67.3 \mathrm{~mm} / 47$ years) (Table 5).

As we motioned before, Center also tended to warm. Summer days were the hot extreme that evidenced the most relevant change (16.4 days/47 years), corresponding to the highest values of all the study area. Cold extremes tended to decrease. Frost days were the most decreasing index with 13.7 days/47years. Finally, precipitation extremes were characterized by a dryness trend, evidencing a decreasing in most of the indices (Table 5).

The South had a positive trend in hot extremes. For instance, warm nights (TN90p) had a statistically significant increase (3.4 days/period). Cold extremes had a negative trend with values similar to Center. Precipitation extremes presented a mixed trend with positive values in PRCPTOT and R10, and negative in Rx1 and Rx5 days (Table 5).

\subsection{Temperature and precipitation structural changes}

Precipitation showed structural changes in 2002 (breakpoint) in the sub-regions North, Center and Northeast, whereas in the South this occurred in 2001. When we analyzed the maximum temperature, the breakpoint was observed during 2005 in Center and South, in 2002 in the Northeast, and during 2006 in North. Finally, the minimum temperature had structural changes during 2006 in the North and 2005 in the rest of the sub-regions (Fig. 6).

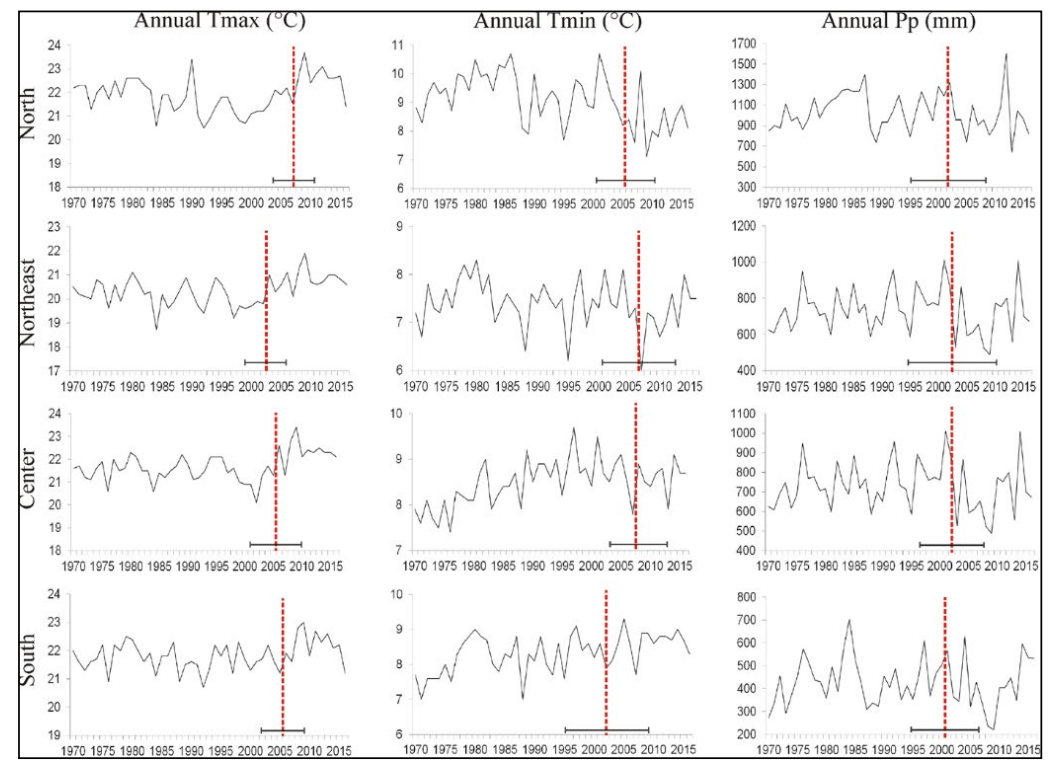

Figure 6. Breakpoints obtained for maximum temperature (Tmax), minimum temperature (Tmin), and Precipitation $(P p)$ for each sub-region. 


\subsubsection{Temperature and precipitation spatial changes in series $A$ and $B$}

We observed spatial changes in these three meteorological variables. Precipitation in the sub-series B (2002-2017 in North, Northeast, and Center and 2001-2017 in South) presented a dryer condition in the center and south than in the sub-period A, which produced a decrease of $100 \mathrm{~mm}$ year $^{-1}$, approximately. The north of the study area showed a similar behavior between both series (Fig. 7). Minimum Temperature (Tmin) depicted a hot trend over the area. The most elevated area (Northeast) had a minimum increase. However, the rest of the area presented values oscillating between 3 and $1.5^{\circ} \mathrm{C}$. Despite this, North represented the area with a negative trend, displaying values of $1^{\circ} \mathrm{C}$ lower in period $\mathrm{B}$ respect to A (Fig. 7). Finally, maximum temperature (Tmax) had the main changes between both series. All the study area had an increase of $1^{\circ} \mathrm{C}$, showing a warming trend in the last 15 years (Fig. 7).

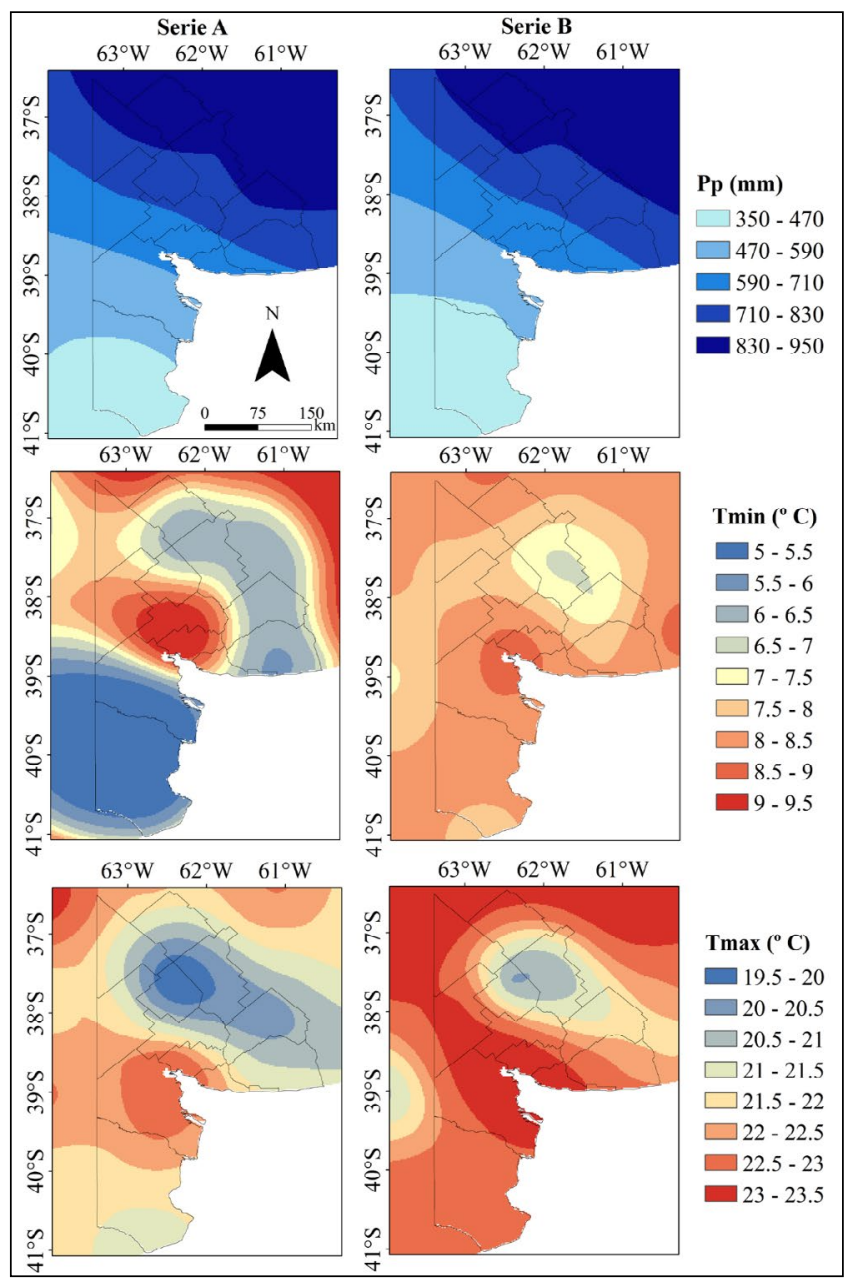

Figure 7. Temperature and precipitation structural changes in the South of Pampas, considering both series ( $A$ and $B$ ). 


\subsubsection{Trend analyses of daily extremes in series $A$ and $B$}

On the other hand, we calculated the trends of daily temperature and precipitation extremes for two-time series (A and B). North presented the main changes in cold extremes indices (Tminmean, TNn, TXn, TN10p, FD0, and DTR), in three derived from hot extremes (Tmaxmean, TN90p, and SU), and in only one from precipitation extremes (Rx5days) (Table 6). The Rx5days decreased by $12 \mathrm{~mm}$ over the last 15 years. On the other hand, a significant increase of Tmaxmean was recorded $\left(0.6^{\circ} \mathrm{C} / 15\right.$ years $)$, whereas TN90p decreased as well as Tminmean $\left(-1.1^{\circ} \mathrm{C} / 15\right.$ years $)$. As a consequence, a decrease in coldest night (TNn) occurred, and an increase in cool days (Tx10p), cool nights (TN10p) and frost days (FD0). However, summer days (SU25) increased in the last 15 years (Table 6).

The Northeast presented statistically significant changes in the maximum and minimum temperatures, but not in precipitation (Table 6). As in the North sub-region, the maximum temperature increased by $0.6^{\circ} \mathrm{C}$ over the last eleven years. However, warm nights (TN90p) have declined. Minimum temperature had a cooling trend, registering $0.3{ }^{\circ} \mathrm{C}$ less during the previous eleven years (Table 6).

In the Center sub-region, very wet days (R95p) were reduced by 25 days/15 years. As in the two sub-regions described below, a positive trend in maximum temperature $\left(0.6^{\circ} \mathrm{C} / 15\right.$ years) was recorded. Moreover, TNn decreased $0.6^{\circ} \mathrm{C} / 15$ years (Table 6$)$. The sub-region South had a particular pattern that made it different from the rest of the regions. Most of the significant changes in precipitation extremes were recorded for this climate type. We observed a decrease in very wet days (20 days), extremely wet days (17 days) and in Rx1day (10 mm), during the last 15 years (Table 6).

\section{Discussion}

The climate regionalization of the south of Pampas allows us to identify this as an area highly vulnerable to short-term climate variability, and its condition is exacerbated in a north-south direction. In this context, it is remarkable to consider that the semi-arid regions have a rainfall gradient influenced by their limiting condition between humid and arid environments (Aliaga et al., 2017).

The analysis of trends of daily temperature and precipitation extremes in each climatic sub-region resulted in an evaluation of the magnitude of the spatiotemporal changes and their effects on the south of the Pampas (Argentina) during the period 1970-2017. These indices have been applied worldwide to identify the thermal and rainfall changes on a daily scale (Vincent and Mekis, 2006; Chen et al., 2017, Worku et $a l ., 2018$ ). The climate structural changes (or breakpoints) established that all the study area presented statistical differences in the last 15 years (Table 6). The most critical changes in minimum temperature occurred in the North and Northeast, whereas the maximum temperature in the Center. Finally, the South was the only one that presented statistically significant changes in precipitation. Thus, we demonstrated that the spatial distribution of rainfall has an intricate pattern that is in line with the results of Westra et al. (2013). 


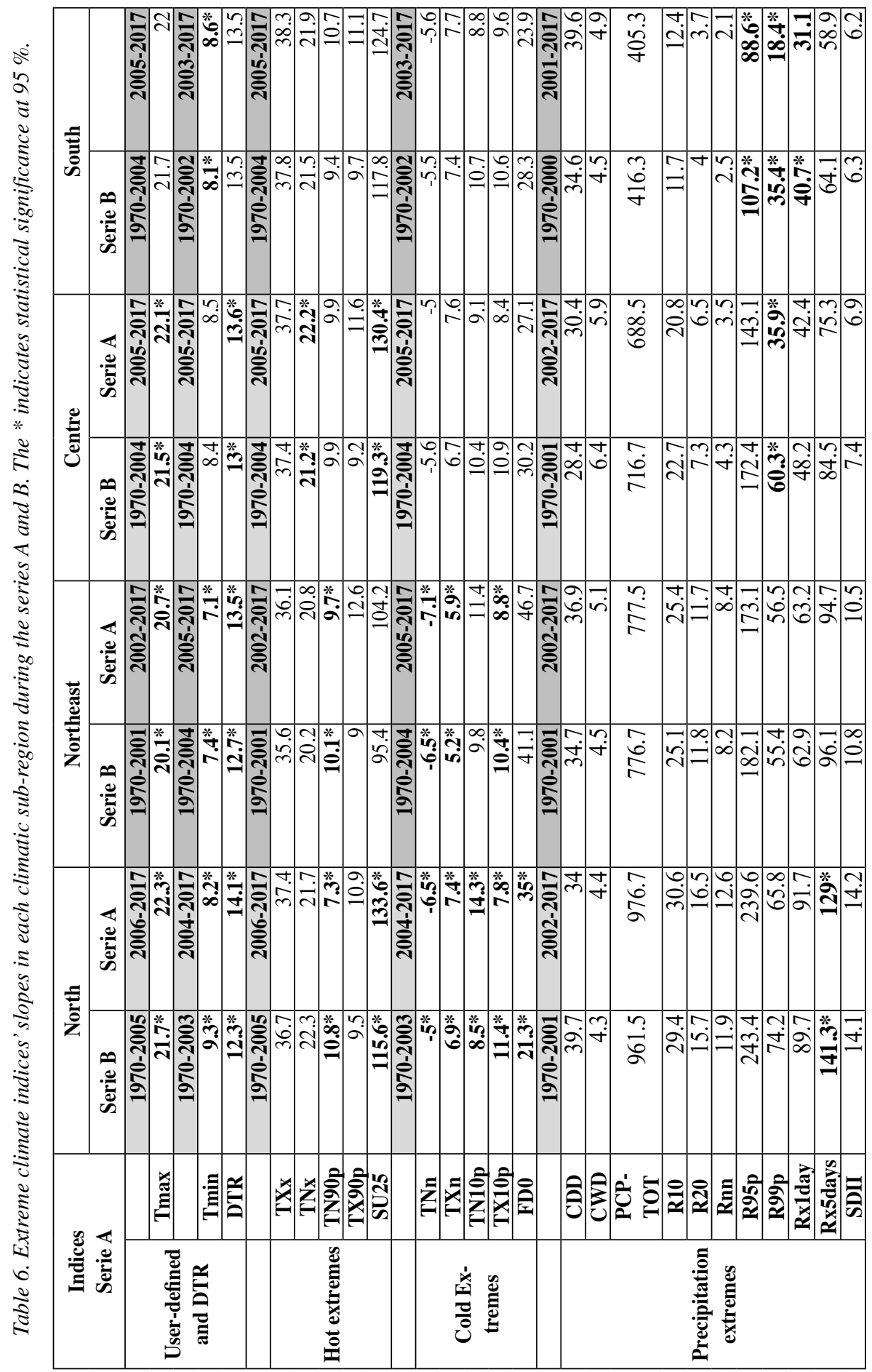


Moreover, the south of the Pampas and particularly the North, Northeast, and Center sub-regions presented warming trends associated with higher values of summer days (SU25), and an increase of the maximum temperature. Therefore, the study area is exposed to global warming (Shahid, 2010, Abatan et al., 2016). The temperature and precipitation extremes, for instance, very heavy rains, heavy rains, frost days, summer days, etc. have a direct impact on agriculture, livestock production, and the population (Worku et al., 2018), especially in semiarid regions (Salman et al., 2017). The increase in the minimum and maximum temperatures observed in the south of the Pampas generates more available energy, which could affect the flowering and the delay in the crop growing season. Besides, this situation could shorten the critical period and therefore reduce yields (Fernandez-Long et al., 2013).

Nevertheless, minimum temperature has a positive trend (except in Northeast) augmenting the intensity of TNn. Frost days have a negative slope in the Center and Northeast sub-regions. These results are related to relevant short-term climate variability, and it was higher than in other regions of the world (Chen et al., 2017; Worku et al., 2018). This evidence is in line with other studies from Argentina, which have demonstrated that the center of the country presented a negative and progressive trend of frost days (Barrucand and Rusticucci, 2001; Fernandez-Long et al., 2013) and in the Pampas (Fernandez-Long et al., 2005). Conversely, we found that frost days have increased in the sub-regions North and Northeast. This condition could increase the frost risk with indirect potential crop damage (Fernandez-Long et al., 2005), particularly in this area where the main economic activity is the rain-fed agriculture and livestock.

In the south of Pampas, there was evidence that cold days, as well as warm nights, presented negative trends, but warm days and cold nights had a positive one. The relevance of studying cool days trends (TX10p), cold nights (TN10p), as well as warm ones (TX90p and TN90p, respectively) is that it could be useful for estimating the existence of an earlier start or a delayed end to the crop growing season (Menzel et al., 2003; Fernandez-Long et al., 2013). A similar situation is presented with TNn because its knowledge could contribute to getting an improvement in crop yields. For example, thermal variations could generate an increase in diseases and pests in crops (Grassini et al., 2011; Worku et al., 2018).

Conversely, precipitation did not present a spatial homogeneity because it increased in the North and Northeast sub-regions and decreased in the Center and South over the last 15 years (Table 6). The sub-region South has been the only one that presents significant changes in precipitation since 2001. For this reason, this sub-region could be exposed to wind erosion processes as a consequence of the high number of consecutive dry days. The increase in this index generates the advance of degradation and desertification processes in different semiarid regions in the world (Reynolds et al., 2005; Vicente Serrano et al., 2012), and especially in the south of the Pampas (Gabella et al., 2016). Moreover, this situation could change crop cycles as well as the reduction of the availability of water for human consumption (Aliaga et al., 2016; Ferrelli, 2016).

Finally, we consider that the knowledge of the short-term variability based on temperature and precipitation extremes in different areas of the world is essential because it provides necessary information for stakeholders to design adaptation strategies for climate 
change. These could be aimed at reducing the adverse effects on crop yields, grasslands, livestock, water availability for agricultural activities (Worku et al., 2018), and human consumption. The climate variability could be more severe in those areas with rain-fed agriculture, such as arid and semiarid regions. In Argentina, these regions have an extension of $75 \%$ of the territory. In this context, considering the importance of these areas for the economic activities worldwide, the climatic delimitation, and/or re-delimitation, taking into account the daily temperature and precipitation extremes, needs to be considered as an essential point for achieving an effective management plan for the natural resources focused on the permanence of the main economic activities (Tierney et al., 2013).

\section{Conclusion}

The exhaustive analysis of the daily temperature and precipitation extreme allow us to identify four sub-regions. This regionalization permitted to determine the trend of thermal and rainfall changes at a sub-regional scale. The North was the rainiest; the Northeast was subdivided by the effect of the elevation in the temperature (lowest values of Tmax and Tmin). The Center was the area of transition between rainy regimes and dryness. The South was the only sub-region that tended to aridity, presenting statistically significant changes in precipitation extremes. Therefore, the south of the Pampas is an area characterized by its high dependency on short-term climatic events.

The methodology applied in this study could be easily replayed in any part of the world and is fundamental for delimiting in detail climatic areas. Its application in semiarid regions with rain-fed agriculture and livestock is essential because daily thermal and rainfall extremes determine, for example, crop productions. Finally, the information obtained in this work is pertinent to stakeholders and decision-makers to orientate sustainable management plans and to prevent changes in the structure and function in the ecosystems.

\section{Acknowledgments}

The authors are grateful to the Consejo Nacional de Investigaciones Científicas y Técnicas (CONICET, Argentina) and Universidad Nacional del Sur (UNS) for financial support. This study was also carried out with the aid of a grant from the Inter-American Institute for Global Change Research (IAI) CRN3038, which is supported by the US National Science Foundation (Grant GEO-1128040). Moreover, we would like to thank the Instituto Nacional de Tecnología Agropecuaria (INTA), and Servicio Meteorológico Nacional (SMN) from Argentina for providing meteorological data. Finally, the authors would like to thank Rosemary Scoffield for reviewing the language of the manuscript. The first two authors contributed equally to this work.

\section{References}

Abatan, A.A., Abiodun, B.J., Lawal, K.A., Gutowski, W.J. 2015. Trends in extreme temperature over Nigeria from percentile-based threshold indices. International Journal of Climatology 6 (6), 2527-2540. http://doi.org/10.1002/joc.4510. 
Abbate, M.C.L., Molinero, J.C., Guinder, V.A., Perillo, G.M., Freije, R.H., Sommer, U., Spetter, C.V., Marcovecchio, J.E. 2017. Time-varying environmental control of phytoplankton in a changing estuarine system. Science of the Total Environment 609, 1390-1400. https://doi. org/10.1016/j.scitotenv.2017.08.002.

Abson,D.J.,Dougill, A.J., Stringer,L.C.2012.Using principal component analysis for informationrich socio-ecological vulnerability mapping in Southern Africa. Applied Geography 35 (1), 515-524. https://doi.org/10.1016/j.apgeog.2012.08.004.

Aliaga, V.S., Ferrelli, F., Alberdi-Algarañaz, E.D., Bohn, V.Y., Piccolo, M.C. 2016. Distribution and variability of precipitation in the Pampas, Argentina. Cuadernos de Investigación Geográfica 42 (1), 261-280. http://doi.org/10.18172/cig.2867.

Aliaga, V. S., Ferrelli, F., Piccolo, M. C. 2017. Regionalization of climate over the Argentine Pampas. International Journal of Climatology 37, 1237-1247. https://doi.org/10.1002/ joc.5079.

Barrucand, M., Rusticucci, M. 2001. Climatología de temperaturas extremas en la Argentina. Variabilidad temporal y regional. Meteorológica 26 (1-2), 85-102.

Berndt, C., Haberlandt, U. 2018. Spatial interpolation of climate variables in Northern GermanyInfluence of temporal resolution and network density. Journal of Hydrology: Regional Studies $15,184-202$.

Chen, A., He, X., Guan, H., Cai, Y. 2017. Trends and periodicity of daily temperature and precipitation extremes during 1960-2013 in Hunan Province, central south China. Theoretical and Applied Climatology 132 (1-2), 71-88. https://doi.org/10.1007/s00704-017-2069-x.

Fernández-Long, M.E., Barnatán. I.E., Spescha, L.B., Hurtado, R.H., Murphy, G.M. 2005. Caracterización de las heladas en la Región Pampeana y su variabilidad en los últimos 10 años. Revista Facultad de Agronomía 25 (3), 247-257.

Fernández-Long, M.E., Müller, G.V., Beltrán-Przekurat, A., Scarpati, O.E. 2013. Long-term and recent changes in temperature-based agroclimatic indices in Argentina. International Journal of Climatology 33 (7), 1673-1686. https://doi.org/10.1002/joc.3541.

Ferrelli, F. 2016. Efectos de eventos El Niño y La Niña sobre las lagunas del sur de la Región Pampeana (Argentina). InterEspaço: Revista de Geografia e Interdisciplinaridade 2, 122142.

Ferrelli,F., Piccolo, M.C. 2017. Estudio del confort climático a escala micro-local.El caso de Bahía Blanca (Argentina). Bitácora Urbano Territorial 27 (3), 91-100. http://doi.org/10.15446/ bitacora.v27n3.56995.

Gabella, J.L., Campo, A.M. 2016. Procesos de ocupación y construcción del espacio rural pampeano: el caso del partido de Patagones. Huellas 20, 79-99. http://doi.org/10.19137/ huellas.

Grassini, P., Thorburn, J., Burr, C., Cassman, K.G. 2011. High-yield irrigated maize in the Western U.S. Corn Belt: I. On-farm yield, yield potential, and impact of agronomic practices. Field Crops Research 120, 142-150. https://doi.org 10.1016/j.fcr.2010.09.012.

IPCC 2012. Managing the risks of extreme events and disasters to advance climate change adaptation. In: C.B.V. Barros, T.F. Stocker, D. Qin, D.J. Dokken, K.L. Ebi, M.D. Mastrandrea, K.J. Mach, G.-K. Plattner, S.K. Allen, M. Tignor, P.M. Midgley (Eds.), A special report of working groups I and II of the intergovernmental panel on climate change (IPCC). Cambridge University press, Cambridge, UK, and New York, USA, pp. 555-564.

IPCC 2013. Climate change 2013: The physical science basis. In: T.F. Stocker, D. Qin, G.-K. Plattner, M. Tignor, S.K. Allen, J. Boschung, A. Nauels, Y. Xia, V. Bex, P.M. Midgley (Eds.), Contribution of Working Group I to the Fifth Assessment Report of the Intergovernmental Panel on Climate Change. Cambridge University Press: Cambridge, UK, and New York, USA, 1535 pp. 
Irwin, S., Simonovic, S.P., Burn, D.H. 2017. Delineation of precipitation regions in two Canadian study areas: the role of the temporal resolution of the precipitation data. Hydrological Sciences Journal 62 (13), 2061-2071.

Kendall, M.G. 1975. Rank correlation methods. Griffin, London.

Kondrashov, D., Denton, R., Shprits, Y.Y, Singer, H.J. 2014. Reconstruction of gaps in the past history of solar wind parameters. Geophysical Research Letters 41 (8), 2702-2707. https:// doi.org/10.1002/2014GL059741.

Lu, W., Atkinson, D.E., Newlands, N.K. 2017. ENSO climate risk: predicting crop yield variability and coherence using cluster-based PCA. Modeling Earth Systems and Environment 3 (4), 1343-1359. https://doi.org/10.1007/s40808-017-0382-0

Mann, H.B. 1945. Non-parametric tests against trend. Econométrica 13, 245-259. https://doi. org/10.2307/1907187.

Marzban, C., Sandgathe S. 2005. Cluster analysis for verification of precipitation fields. Weather and Forecasting 21, 824-838. https://doi.org/10.1175/WAF948.1.

Menafoglio, A., Secchi,P., Dalla, R.M. 2013. A Universal Kriging predictor for spatially dependent functional data of a Hilbert Space. Electronic Journal of Statistics 7, 2209-2240.

Menzel, A., Jakobi, G., Ahas, R., Scheifinger, H., Estrella, N. 2003. Variations of the climatological growing season (1951-2000) in Germany compared with other countries. International Journal of Climatology 23, 793-812. https://doi.org/10.1002/joc.915.

Monzón, J.P., Sadras, V.O., Abbate, P.A., Caviglia, O. P. 2007. Modeling management strategies for wheat-soybean double crops in the south-eastern Pampas. Field Crops Research 101, 4452. https://doi.org/10.1016/j.fcr.2006.09.007.

O'Rourke, N., Psych, R., Hatcher, L. 2013. A step-by-step approach to using SAS for factor analysis and structural equation modeling. Sas Institute.

Peterson, T., Folland, C., Gruza, G., Hogg, W., Mokssit, A., Plummer, N. 2001. Report on the activities of the working group on climate change detection and related rapporteurs. World Meteorological Organization, Geneva, $146 \mathrm{pp}$.

Qamar, M.U., Azmat, M., Shahid, M.A., Ganora, D., Ahmad, S., Cheema, M.J.M., Faiz, M.A., Sarwar, A., Shafeeque, M., Khan, M.I. 2017. Rainfall extremes: a novel modeling approach for regionalization. Water Resources Management 31 (6), 1975-199.

Reynolds, J.F., Maestre, F.T., Huber-Sannwald, E., Herrick, J., Kemp, P.R. 2005. Aspectos socioeconómicos y biofísicos de la desertificación. Revista Ecosistemas 14 (3), 4-21.

Ruml, M., Gregorić, E., Vujadinović, M., Radovanović, S., Matović, G., Vuković, A., Pocuca, V. and Stojičić, D. 2017. Observed changes of temperature extremes in Serbia over the period 1961- 2010. Atmospheric Research 183, 26-41 10.1016/j.atmosres.2016.08.01.

Salguero-Gómez, R., Siewert, W., Casper, B.B., Tielbörger, K. 2012. A demographic approach to study the effects of climate change in desert plants. Philosophical Transactions of the Royal Society of London B: Biological Sciences 367(1606), 3100-3114. http://doi.org/10.1098/rstb.2012.0074.

Salman, S.A., Shahid, S., Ismail, T., Chung, E.S., Al-Abadi, A.M. 2017. Long-term trends in daily temperature extremes in Iraq. Atmospheric Research, 198, 97-107.

Sen, P. K. 1968. Estimates of the regression coefficient based on Kendall's tau. Journal of the American Statistical Association 63 (324), 1379-1389. https://doi.org/10.2307/2285891.

Shahid, S. 2010. Recent trends in the climate of Bangladesh. Climate Research 42 (3), 185-193. https:doi.org/10.3354/cr00889.

Shi, P., Sun, S., Gong, D., \& Zhou, T. 2016. World regionalization of climate change (1961-2010). International Journal of Disaster Risk Science 7 (3), 216-226.

Shrestha, A.B., Bajracharya, S.R., Sharma, A.R., Duo, C., Kulkarni, A. 2017. Observed trends and changes in daily temperature and precipitation extremes over the Koshi river basin 19752010. International Journal of Climatology 37(2), 1066-1083. 
Song, C., Pei, T., Zhou, C. 2014. The role of changing multiscale temperature variability in extreme temperature events on the eastern and central Tibetan Plateau during 1960-2008. International Journal of Climatology 34 (14), 3683-3701. https://doi.org/10.1002/joc.3935.

Taylor, M.H., Losch, M., Wenzel, M., Schröter, J. 2013. On the sensitivity of eld reconstruction and prediction using empirical orthogonal functions derived from Gappy data. Journal of Climate 26 (22), 9194-9205. https://doi.org/10.1175/JCLI-D-13-00089.1.

Tierney, J., Smerdon, J., Anchukaitis, K., Seager, R. 2013. Multidecadal variability in East African hydroclimate controlled by the Indian Ocean. Nature 493, 389-392. https://doi.org/10.1038/ nature 11785 .

Vicente-Serrano, S.M., Zouber, A., Lasanta, T., Pueyo, Y. 2012. Dryness is accelerating degradation of vulnerable shrublands in semiarid Mediterranean environments. Ecological Monographs 82 (4), 407-428. https://doi.org/10.1890/11-2164.1.

Viglizzo, E.F. 2018. Cambio climático y seguridad alimentaria global: Oportunidades y amenazas para el sector rural argentino. Anales de la ANAV 69, 150-181.

Vincent, L.A., Mekis, E. 2006. Changes in daily and extreme temperature and precipitation indices for Canada over the twentieth century. Atmosphere-Ocean 44 (2), 177-193. https://doi. org/10.3137/ao.440205.

Wang, X.L., Wen, Q.H., Wu, Y. 2007. Penalized maximal t test for detecting undocumented mean change in climate data series. Journal of Applied Meteorology and Climatology 46, 916-931 https://doi.org/10.1175/JAM2504.1.

Wang, X.L. 2008a. Penalized maximal F-test for detecting undocumented mean shifts without trend-change. Journal of Atmospheric and Oceanic Technology 25, 368-384. https://doi. org/10.1175/2007JTECHA982.1.

Wang, X.L. 2008b. Accounting for autocorrelation in detecting mean-shifts in climate data series using the penalized maximal t or F test. Journal of Applied Meteorology and Climatology 47, 2423-2444 https://doi.org/10.1175/2008JAMC1741.1.

Wang, X.L., Chen, H., Wu, Y., Feng, Y., Pu, Q. 2010. New techniques for the detection and adjustment of shifts in daily precipitation data series. Journal of Applied Meteorology and Climatology 49 (12), 2416-2436. https://doi.org/10.1175/2010JAMC2376.1.

Whan, K., Alexander, L.V., Imielska, A., McGree, S., Jones, D., Ene, E., Finaulahi, S., Inape, K., Jacklick, L., Kumar, R., Laurent, V., Malala, H., Malsale, P., Pulehetoa-Mitiepo, R., Ngemaes, M., Peltier, A., Porteous, A., Seuseu, S., Skilling, E., Tahani, L., Toorua, U., Vaiimene, M. 2013. Trends and variability of temperature extremes in the TropicalWestern Pacific. International Journal of Climatology 34 (8): 2585-603. https://doi.org/10.1002/joc.3861 .

Westra, S., Alexander, L.V., Zwiers, F.W. 2013. Global increasing trends in annual maximum daily precipitation. Journal of Climate 26 (11), 3904-3918. https://doi.org/10.1175/ JCLI-D-12-00502.1.

Worku, G., Teferi, E., Bantider, A., Dile, Y.T. 2018. Observed changes in extremes of daily rainfall and temperature in Jemma Sub-Basin, Upper Blue Nile Basin, Ethiopia. Theoretical and Applied Climatology 1-16. https://doi.org/10.1007/s00704-018-2412-x.

Zapperi, P.A. 2014. Caracterización del escurrimiento urbano en la ciudad de Bahía Blanca. Revista Universitaria de Geografía 3 (2), 125-150.

Zhang, X., Alexander, L., Hegerl, G. C., Jones, P., Tank, A. K., Peterson, T. C., Trewin, B., Zwiers, F. W. 2011. Indices for monitoring changes in extremes based on daily temperature and precipitation data. Wiley Interdisciplinary Reviews: Climate Change 2 (6), 851-870. https://doi.org/10.1002/wcc.147.

Zhang, X., Yang, F. 2013 RClimDex (1.1) user manual. Available at http://cccma.Seos.Uvic.Ca/ ETCCDI/software.shtml. (last access:14/04/2018).

Zhou, H., Aizen, E., Aizen, V. 2018. Constructing a long-term monthly climate data set in central Asia. International Journal of Climatology 38, 1463-1475. https:doi.org/10.1002/joc.5259. 